\title{
"Impact of Industry 4.0 on labor productivity in the Slovak Republic"
}

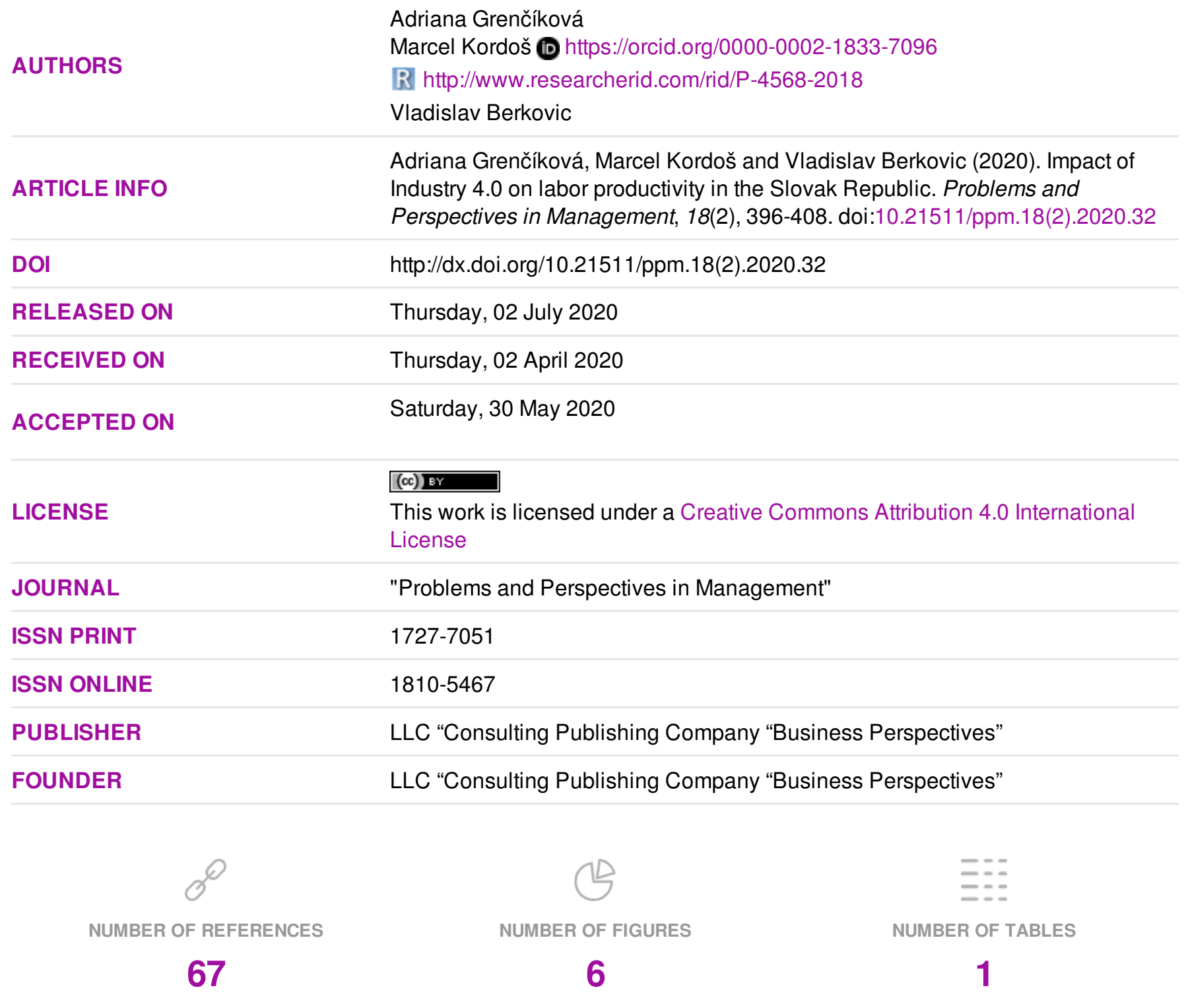

(c) The author(s) 2022. This publication is an open access article. 


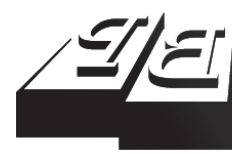

\section{BUSINESS PERSPECTIVES}

(O)

LLC "CPC "Business Perspectives" Hryhorii Skovoroda lane, 10, Sumy, 40022, Ukraine www.businessperspectives.org
Received on: $2^{\text {nd }}$ of April, 2020 Accepted on: $30^{\text {th }}$ of May, 2020 Published on: $2^{\text {nd }}$ of July, 2020

() Adriana Grencikova, Marcel Kordos, Vladislav Berkovic, 2020

Adriana Grencikova, Ph.D., Dr., Department of Personnel Management and Human Resources, Faculty of Social and Economic Relations, Alexander Dubcek University in Trencin, Slovak Republic. (Corresponding author)

Marcel Kordos, Ph.D., Department of Public Administration and Regional Economy, Faculty of Social and Economic Relations, Alexander Dubcek University in Trencin, Slovak Republic.

Vladislav Berkovic, Ph.D. Student, Department of Personnel Management and Human Resources, Faculty of Social and Economic Relations, Alexander Dubcek University in Trencin, Slovak Republic.
Adriana Grencikova (Slovak Republic), Marcel Kordos (Slovak Republic), Vladislav Berkovic (Slovak Republic)

\section{IMPACT OF INDUSTRY 4.0 ON LABOR PRODUCTIVITY IN THE SLOVAK REPUBLIC}

\begin{abstract}
The Fourth Industrial Revolution bears major technological, demographic, and socioeconomic changes affecting nearly every area in business. Within the human resources area, both a surplus of labor and the creation of brand new professions are to be expected. Industry 4.0 concept significantly affects labor productivity in individual countries and does not miss the Slovak Republic either. All segments of the labor market, not just industrial enterprises, will be affected. The present study aims to analyze the possible development of labor productivity in Slovak companies and determine its development in the next period, considering the decreasing number of working-age populations in terms of the fallouts on creation and termination of jobs and occupations. The questionnaire carried out in 319 enterprises in the Slovak Republic with a received response of 228 was a key research tool used to analyze the results of the survey. The findings show that although the labor force within the Slovak labor market will not increase, the labor force will decrease due to unfavorable demographic development. The overall productivity in Slovak companies will increase due to the new technologies implementation. The results have proved that the Industry 4.0 concept will significantly affect labor productivity in the world economy and the Slovak Republic. In particular, the recommendations aim to draw attention to changes in job structure and the need to reform the education system because of Industry 4.0 requirements.
\end{abstract}

Keywords employees, Slovak enterprises, automation, robotics, new jobs creation

JEL Classification F63, O31

\section{INTRODUCTION}

Labor productivity in the Slovak Republic has an increasing trend, so it can be concluded that the economy produces more final products and services. According to Mura and Ključnikov (2018) and Krajňáková and Vojtovič (2017), this fact is caused not only by increased demand for goods and services produced in the territory of Slovak Republic, as a result of which the demand for labor is increasing but also by the implementation of artificial intelligence in production processes and other spheres of society. As an illustrative example, while in hypermarkets, older generations are used to waiting in long lines to be served by a hypermarket employee, it is common for them to be assisted by automatic self-service cash registers in shops. As long as one employee can now assist approximately six self-service cash registers, a single classic cash register is assisted by one employee. This means that, after automation being implemented, the labor productivity of 1 employee is to be six times bigger than of an employee at the classic cash register (Gorlevskaya, Kubičková, Fodranová, \& Žák, 2018; Gress, Lipkova, \& Harakal'ova, 2016; Toth, M. Maitah, \& K. Maitah, 2019).

The present study aims to determine its impact and further development concerning employers' behavior based on the analysis of labor productivity development in the Slovak Republic within the Industry 
4.0 concept implementation. Considering the issue having been mentioned above, the paper will deal with the impacts of changes within the development of labor productivity in the Slovak business environment on the creation and termination of jobs and occupations being associated with the implementation of the Industry 4.0 concept. Based on the facts mentioned above, the outline of the paper is as follows. Firstly, the development of an economically active population from 2012 to 2019 and the labor productivity per economically active population in the Slovak Republic were observed and analyzed. Secondly, the relationship of the number of economically active population with labor productivity increase was assessed in terms of its development prediction. Thirdly, the questionnaire survey analysis results on the impact of the number of employees within the Industry 4.0 implementation and the reasons why Industry 4.0 should be implemented in enterprises was carried out. Finally, the development of labor productivity in the Slovak Republic, the USA, Japan, and Germany was compared and analyzed.

\section{LITERATURE REVIEW}

Many authors such as Cihelková, Nguyen, Fabuš, and Čimová (2020), Okręglicka, Havierniková, Mynarzová, and Lemańska-Majdzik (2017) and Simionescu, Bilan, Krajňáková, Streimikiene, and Gẹdek (2019) point out that industrial production has undergone significant changes over the last few centuries, has had a significant impact on production methods, as well as the social environment and the quality of life of employees. According to Dano and Lesakova (2018) and Šauer, Kolínský, and Prášek (2019), the Fourth Industrial Revolution is a concept based on the German Industry 4.0 concept. Experts are not entirely in agreement with anticipating the result of this concept implementation. Obadi and Korcek (2018) argue that the Internet of Things appears to be one of the sub-concepts of Industry 4.0. In the next ten years, all machines and some of the components in them will be able to communicate with each other. Hnát, Zemanová, and Machoň (2016) and Fojtikova and Stanickova (2017) state that in conjunction with other technologies such as digital enterprise, intelligent robots working with people, huge amount of data, machine learning and artificial intelligence, the production will gain the ability to be self-managed and self-organized. De Castro and Hnat (2017) highlight that it will be a system with decentralized control and autonomous decision-making - an intelligent factory will be created, indicated by experts as the cyber-physical system. Jeníček (2016) and Machkova and Sato (2017) claim that these changes will fundamentally affect the life of human society; therefore, it is necessary to expect changes in all areas of society. Mura, Havierniková, and Machová (2017) and Piha, Pohjanheimo, Lähteenmäki-
Uutela, Křečková, and Otterbring (2018) argue that the Industry 4.0 concept is closely related to the concept of Work 4.0, which, in short, represents a form of lifelong acquisition of new working knowledge, skills, and abilities to meet employers' requirements. According to Machková (2013) and Navickas, Vojtovic, and Svazas (2017), considering the emerging trends, the focus within the education must be on skills and knowledge that will enable the workforce to act in the area of new technologies and artificial intelligence. In addition to significant changes in working process and social area, there are significant changes also to be expected in the education system of particular countries and education area in general (Grmelová, 2019a; Belás, Vojtovič, \& Ključnikov, 2016; Sadílek \& Zadražilová, 2015).

Schwab (2018) and Zagata, Hrabák, and Lošták (2019) assert that the Fourth Industrial Revolution bears major technological, demographic, and socio-economic changes affecting nearly every area of business. In the human resources field, there are expected both a surplus of labor and the creation of brand new professions. It is estimated that $65 \%$ of children now attending elementary schools will work in professions that do not exist at present times. Many authors such as Miklosik, Kuchta, Evans, and Zak (2019), Cihelková, Platonova, and Frolova (2019) and Vojtovic (2016) affirm that these facts are already challenging not only for human resources but also for the whole education system, which will have to be able to prepare a new workforce being able to be flexibly adaptable to change conditions regarding knowledge constantly. Ongoing discussions about people, their human, and social dimensions are ubiquitous in terms of Industry 4.0. When it comes to opportunities and 
benefits, the human, social, labor, and environmental factors are key aspects to the objectives of Industry 4.0. Ivanova and Vojtovic (2016) and Taušer, Arltová, and Žamberský (2015) contend that due to the emergence of new technologies, it is expected to improve the temperature, humidity and other measurable and controllable working conditions affecting workplace comfort. According to Sadílek and Zadražilová (2016) and Taušer and Buryan (2011), the crucial issues also will be the safety improvement using rapid detection and increased protection in case of accidents, detection of gases, harmful radiation, fire hazards, including fire prevention and its effective automated disposal. Cepel, Belas, Rozsa, and Strnad (2019) and Jiránková (2012) insist that the possibilities for communication and cooperation will change completely, with an increasing emphasis on ergonomics, emissions reduction, and environment protection.

Gärtner, Sadílek, and Zadražilová (2017) and Maitah and Smutka (2019) say that large manufacturing companies, especially automotive plants, will apply Industry 4.0 mainly to increase production efficiency, where they can increase their production through modernization and automation of production processes, while not requiring more workers but, on the contrary, less. However, workers who will be in particular positions will have to meet the current highly demanding requirements of the labor market. According to Miklošík (2016) and Taušer and Čajka (2014), labor productivity can be defined as total output divided by labor input. It is increasing as a result of improved technologies, higher working skills, and deepening capital. Sejkora and Sankot (2017) argue that labor productivity refers to the volume of values produced per unit of labor consumed over a certain period (year, month, day, hour), depending on the period in which this productivity is detected. Thivant and Machková (2017) and Grmelová (2019b) assert that labor productivity can be distinguished according to what a unit of work is considered to be. If this unit of labor is human labor (labor done by person measured by labor cost - wages), it is about the productivity of living labor. If it is considered the unit of labor to be the work contained in all inputs to a particular transformation process (which results in the production of observed values), it is about the productivity of so- cial work (measured by the price of all inputs into the production process - both living and materialized labor) (Zemanová, Druláková, Peterková, \& Přikryl, 2015; Sauer \& Prasek, 2018; Toth, 2020). Šmejkal and Šaroch (2014) and Tajtáková, Žák, and Filo (2019) contend that to indicate the volume of values produced is also various; for example, at the national economic level, it might be the gross domestic product, gross national product, national income, etc. At this level, the productivity of living labor, expressed by per capita as a specific unit of labor, is usually observed. At the level of individual business entities (associations and companies) producing specific values, it is also possible to express the volume of these produced values more specifically - not only in monetary volume but also in natural units (pieces, kilograms, meters, etc.). Labor consumption at this level is more often referred to as the cost of living and materialized labor. Some authors often encounter indirect reporting of labor productivity - operoseness. Operoseness is the opposite of labor productivity it means the indication of labor to be necessary for a unit of a particular value to be produced (Svačina, Rýdlová, \& Bohácek, 2018; Hnát \& Sankot, 2019). Křečková, Zadražilová, and Řezanková (2016) and Tupa and Krajco (2019) claim that high productivity cuts down costs and reduces production costs, enabling to expand the number of customers or increase profits from each product, to increase wages and dividends, hence, to attract additional investors. According to Šaroch (2015), the factors determining productivity growth are education, research, development, advanced technology solutions in manufacturing, digital technology, and employee motivation.

\section{AIM AND METHODS}

As has been already mentioned, labor productivity is influenced by several indicators. However, some of these indicators cannot be accurately expressed statistically, such as the motivation, skills, and abilities of workers. As the research subject, it has been chosen to develop the number of the economically active population, i.e., a quantifiable indicator, the value of which is affected by the total labor productivity produced in a certain territory in a certain time unit. There is a question regarding the introduction of the Industry 4.0 concept: 
what effect will it have on labor productivity in the future? Initial estimates said that as a result of the Industry 4.0 concept implementation, $50 \%$ of the workforce would be lost in Slovakia; labor productivity per economically active population should increase significantly (Eurostat, 2020).

The present study aims to analyze the impact of Industry 4.0 implementation concept on labor productivity in the Slovak Republic and determine its development in the upcoming period, considering the decreasing working-age population within the impacts on job creation and termination.

Regression analysis of labor productivity development per economically active population, simple analysis, and graphical method were used to figure out the trends.

The labor market meets the demand and supply of labor. Employers represent demand; supply is represented by individuals who are the bearers of specific characteristics within the workforce. In terms of the research within the Vega project No. 1/0430/18 as well as in the opinion of a professional forum such as Industry 4.0, whose main leader is SOVA digital s.r.o., the view of employers on the researched issue is a crucial and significant issue because they and their attitudes will affect the development of labor market in the future, that is why it is very important to deal with this issue. Opponents may argue that employers cannot predict developments in the labor market, but they can predict consumers' behavior relatively accurately, they can very accurately determine the costs on labor and job creation in terms of their strategies. Labor market Forecasts developments are based on the behavior of two entities, particularly labor - supply and employers - demand, so it is very important to assess such a strong impact on their behavior as the Industry 4.0 concept implementation is. Hence, the employers' views have been surveyed in the area of Industry 4.0 implementation. The questionnaire was distributed by random sampling in May 2019 and contained 12 questions; 319 companies in the Slovak Republic were addressed. The response rate of the questionnaire was 228 . The results of some findings are presented further.

\section{RESEARCH RESULTS}

The economically active population (EAP) consists of people who have a permanent job and are actively seeking a job. It means they are registered with the labor office. In Figure 1, the evolution of the economically active population from 2012 to 2019 was observed. In the period under observation between 2012 and 2018, there was a growing number of economically active population between 2012 and 2016. In 2016, the economically active population reached its peak. After this year, the economically active population went into recession, i.e., it declines.

Source: Own processing by Slovak Statistical Office of the Slovak Republic (2020), Datacube (2020).

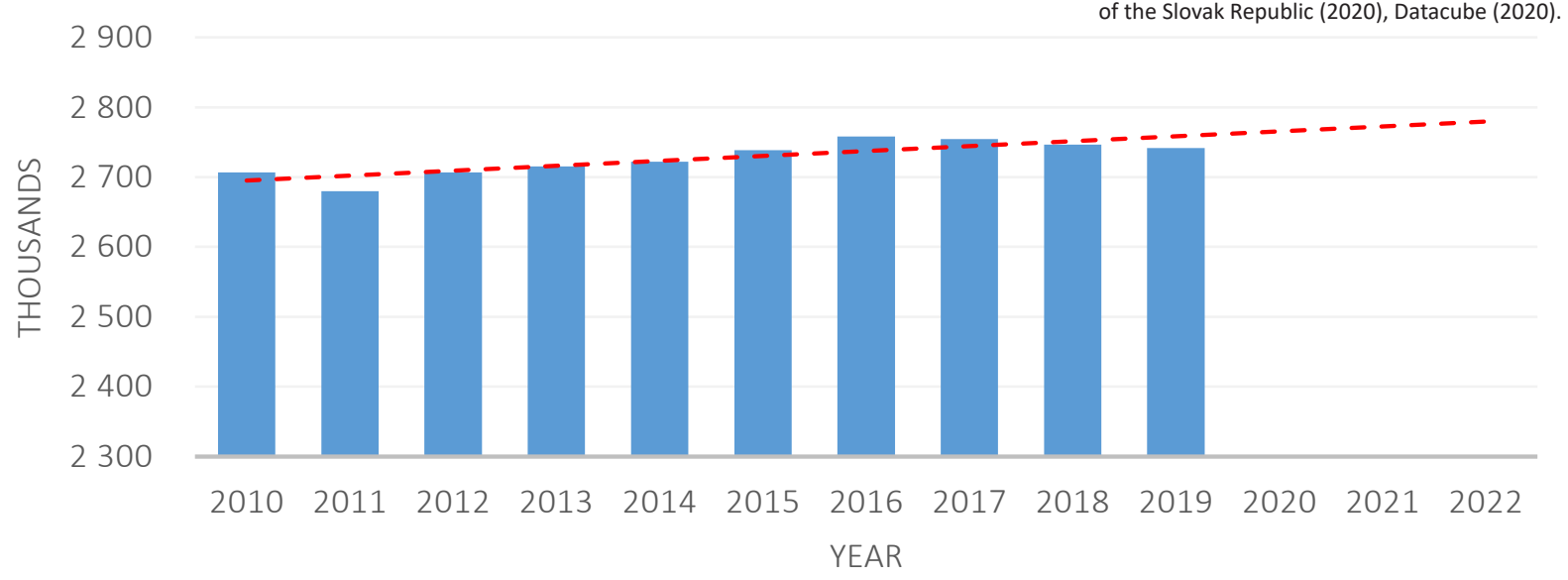

Economically active population - - - Linear (Economically active population)

Figure 1. Economically active population (EAP) in Slovak Republic 
Table 1. Labor productivity

\begin{tabular}{c|c|c|c|c|c|c|c|c|c}
\multicolumn{10}{c}{ Source: Own processing. } \\
\hline Year & $\mathbf{2 0 1 0}$ & $\mathbf{2 0 1 1}$ & $\mathbf{2 0 1 2}$ & $\mathbf{2 0 1 3}$ & $\mathbf{2 0 1 4}$ & $\mathbf{2 0 1 5}$ & $\mathbf{2 0 1 6}$ & $\mathbf{2 0 1 7}$ & $\mathbf{2 0 1 8}$ \\
\hline EAP, thousand EUR & $2,706.5$ & $2,680.0$ & $2,706.5$ & $2,715.3$ & $2,721.8$ & $2,738.3$ & $2,758.1$ & $2,754.7$ & $2,746.3$ \\
GDP at current prices, EUR million & $68,093.0$ & $71,214.4$ & $73,483.8$ & $74,354.8$ & $76,255.9$ & $79,758.2$ & $81,038.4$ & $84,517.0$ & $89,721.0$ \\
Purchasing power per capita, EUR & $25,159.1$ & $26,572.5$ & $27,150.9$ & $27,383.6$ & $28,016.7$ & $29,126.9$ & $29,382.0$ & $30,681.0$ & $32,669.8$ \\
\hline
\end{tabular}

In 2012 , the economically active population (EAP) reached the level of 2,706.5 thousand inhabitants. In 2013 , the economically active population was at the level of 2,715.30 thousand inhabitants, which is 8.8 thousand more than in the previous year. In 2014 , the number of economically active population increased by 6.5 thousand. In 2014, the level of economically active population reached 2,721.80 thousand. In the following year, the economically active population increased again. This time it increased by 16.5 thousand inhabitants and reached the level of 2,738.30 inhabitants. This increase is almost ten times that of the previous year. In 2016, up to $2,758.10$ inhabitants were actively seeking work. The level of the economically active population thus increased by 19.8 thousand inhabitants. After this year, the economic active population's growth reached its peak and, therefore, it began to decline in the following year. In 2017, compared to 2016 , the economically active population dropped by 3.4 thousand inhabitants and reached 2,754.70 people who work or actively seek a job. In the following year, that is, in 2018 , the economically active population was still decreasing. In 2018, it reached the level of 2746.3 thousand inhabitants.
Compared to the previous year, the economically active population decreased by 8.4 thousand inhabitants. The highest increase was registered between the years of 2015 and 2016 by 19.8 thousand inhabitants. The lowest increase in the observed period was recorded between 2016 and 2017, with only 3.4 thousand people working or actively seeking a job. In the period under review, the economically active population on average reached the level of $2,734.43$ thousand people who work or seek jobs. In the next years, a decline in the economically active population was expected, and its forecast is processed in Figure 1. The study's indicator of interest is labor productivity per economically active population, expressed as the ratio of GDP to an economically active population.

In the calculation of labor productivity in Table 1, the total population as one of the basic indicators was not used. However, the number of economically active inhabitants for the survey is a more accurate indicator so that the growth of labor productivity could be expressed. Figure 2 shows the results.

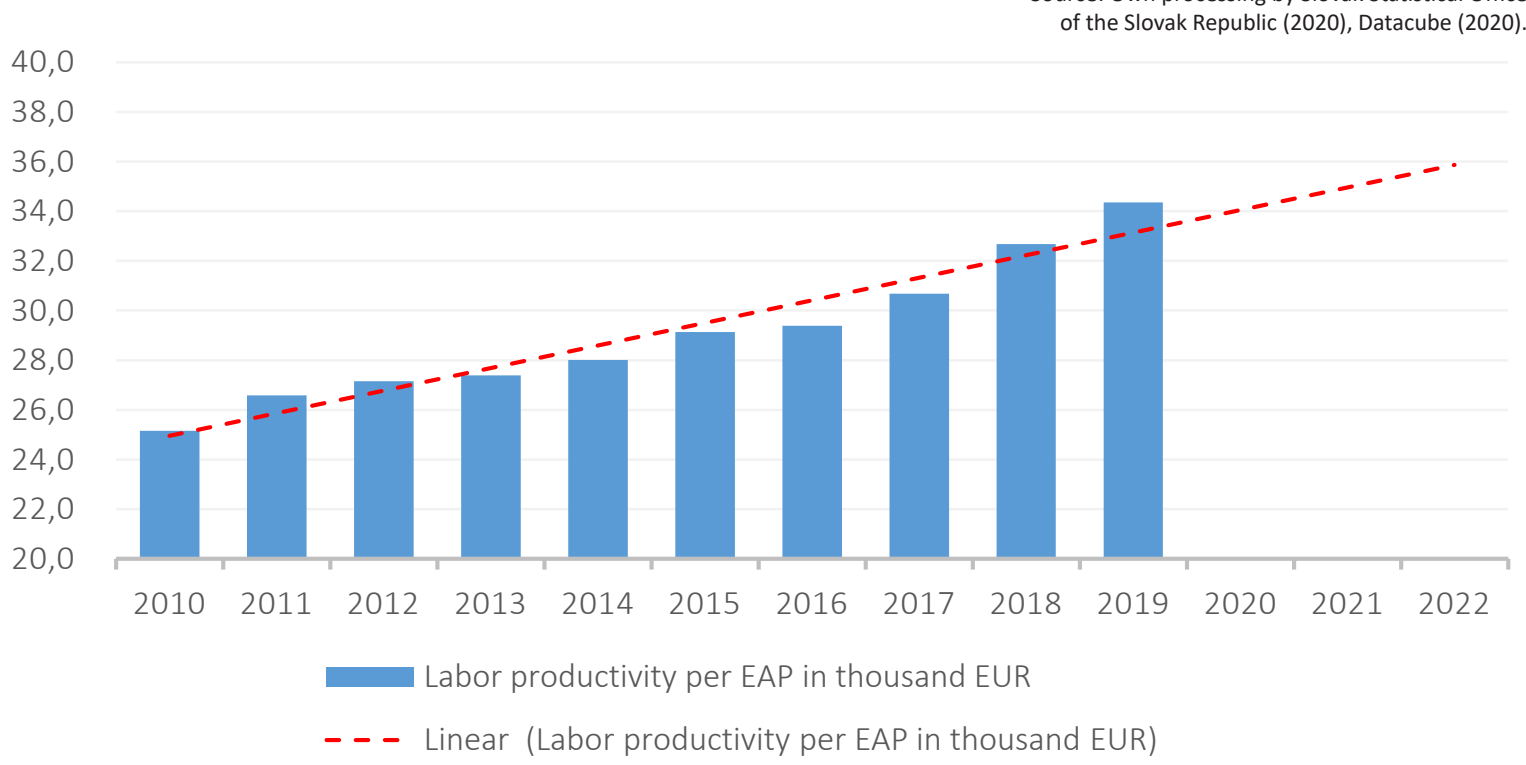

Figure 2. Labor productivity per EAP in thousand EUR 
Labor productivity per economically active inhabitants in the Slovak Republic during the observed period was increasing. At the beginning of the observed period in 2012, it was 26.86 thousand EUR. In the next period in 2013, it increased by 0.46 thousand EUR and reached 27.32 thousand EUR. In 2014, labor productivity per capita also increased. Compared to the previous year, it increased by 0.63 thousand EUR, reaching 27.95 thousand EUR. In the following year, labor productivity per capita did not increase. Compared to the previous year, it increased by 0.95 thousand EUR. In 2015, labor productivity per capita was 28.90 thousand EUR. In 2016, labor productivity per capita reached 29.45 thousand EUR, an increase of 0.55 thousand EUR. It is 0.40 thousand EUR less than the increase between 2014 and 2015. Between 2016 and 2017, the highest growth has been recorded so far. The level of labor productivity per economically active population increased by 1.35 thousand EUR and reached a 30.80 thousand EUR level. Labor productivity per capita has increased even more in the last observed year. Compared to the previous year, the level of labor productivity increased by 2.04 thousand EUR and reached 32.84 thousand EUR. Throughout the observed period, labor productivity per capita was increasing. The fastest recorded growth was between 2017 and 2018, when the average labor productivity per capita was 29.16 thousand EUR.

As being stated in The Future of Jobs Report 2018, the Fourth Industrial Revolution is interacting with other socio-economic and demographic factors to create a perfect storm of business model change in all industries, resulting in major disruptions to labor markets. New categories of jobs will emerge, partly or wholly displacing others. According to the World Economic Forum, the prediction that the share of human and automation would be developing in the future can be described as follows. The rate of automation in the world economy will be leaping in every couple of years dramatically. In 2018, the rate of human force was $71 \%$ and machine force $29 \%$, in 2022 , there will be a drop of human force to $58 \%$ and a big jump of machine force up to $42 \%$, and finally, the prediction shows a changed rate of human force versus automation and robotics in 2025 against 2018 such as $48 \%$ human to $52 \%$ automation in 2025 .

In particular, the implementation of Industry 4.0 will have a big impact on labor productivity. Previous studies of the Slovak Ministry of Economy (2019) reported that $50 \%$ of jobs in the Slovak Republic would be lost due to the size of workers in the automotive industry. However, nowadays, these forecasts are lowered, and they said that the workload would be changed or the workforce will find jobs in new jobs being on the rise. Deployment intensity is an indicator that is currently difficult to be assessed in Slovakia. That is why a questionnaire survey on opinions in companies regarding the Industry 4.0 implementation was conducted. In Figure 3, the answers from the survey conducted in Slovak companies for the question "In which areas do you expect the intelligent industry elements implementation?" are presented.

Source: Own processing

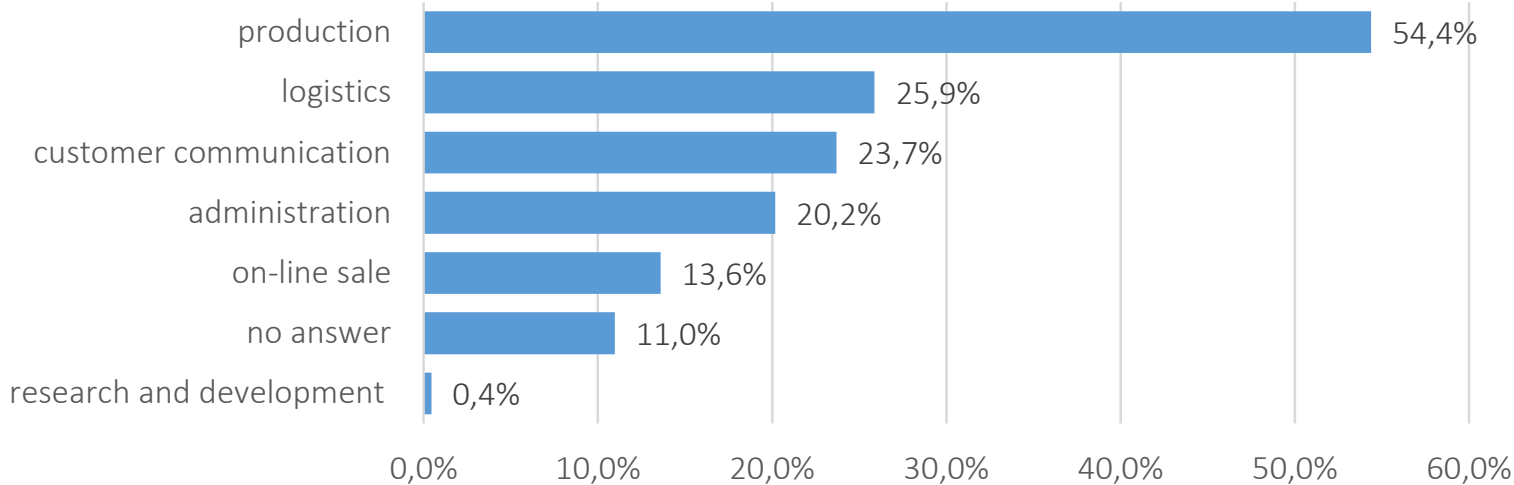

Figure 3. Areas where Industry 4.0 elements are expected to be implemented 


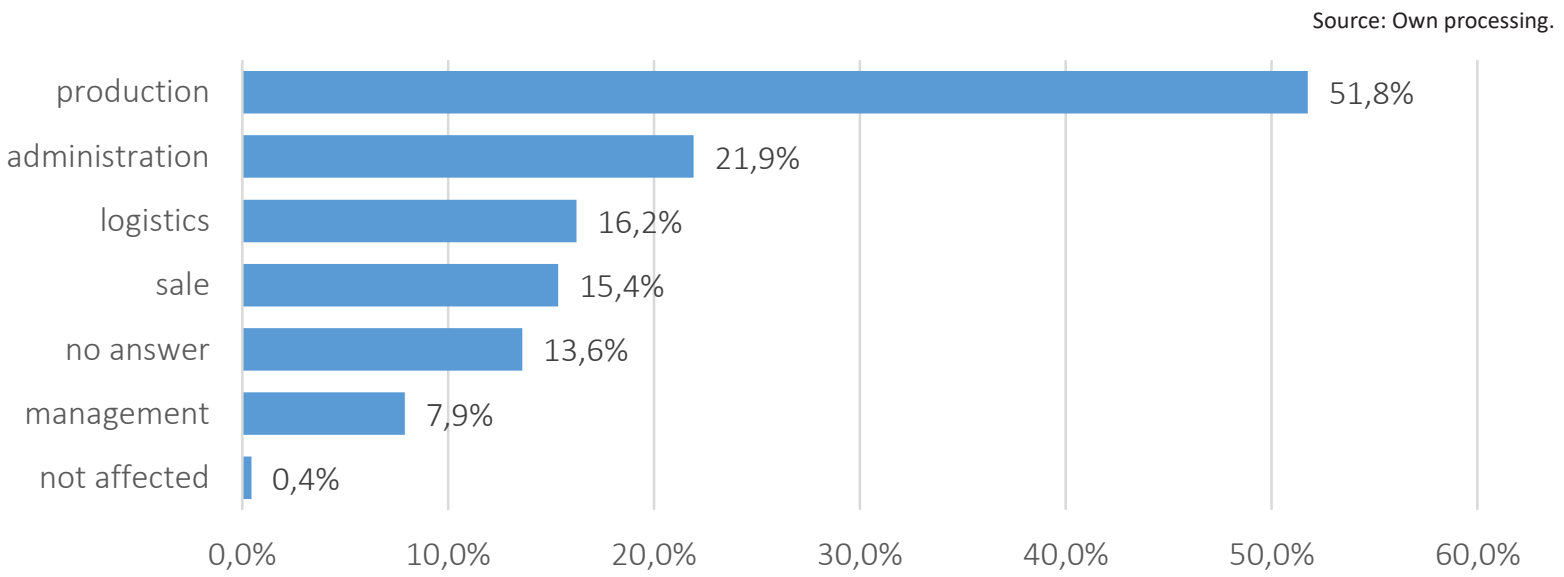

Figure 4. Employers' views on the impact of Industry 4.0 within job creation

From Figure 3, it is clear that most of the jobs concerned will be in the manufacturing sector, where primarily manual jobs are to be replaced or where the health of workers is at risk. It is expected that online sales will increase significantly, but Slovak businesses are not yet responding sufficiently to this trend. A very low percentage of businesses have mentioned the replacement regarding the human work of technicians in the research and development area. However, in this area, a significant increase is expected in the future due to artificial intelligence implementation. The answers to the question "What areas which will be affected by the implementation of Industry 4.0 concept and in which way, e.g., the number of employees?" are presented in Figure 4.

Figure 4 shows that job cuts are indeed projected, especially in the manufacturing and administration sectors. The trend is emerging, for example, in areas like electronic accounting and overall ad- ministration reduction, being relatively a big issue in Slovakia. Only $0.4 \%$ of respondents think that introducing a new concept will not affect the number of jobs, being a relatively negligible number of responses. It is expected that the sales sector will be significantly affected in the future, thanks to communication technologies and increased sales through social networks and applications. It seems that this segment is not yet sufficiently recognized, but sales trends indicate this, as online sales are also taking place on a day when there is a ban on sales such as public and bank holidays in the Slovak Republic and so on and, besides, the cost of living work has increased due to government measures. In Figure 5, the results for the answers to the question regarding "What are the main reasons for the Industry 4.0 implementation in Slovak companies?" are presented.

The relatively low percentage of respondents attaches importance to product personalization,

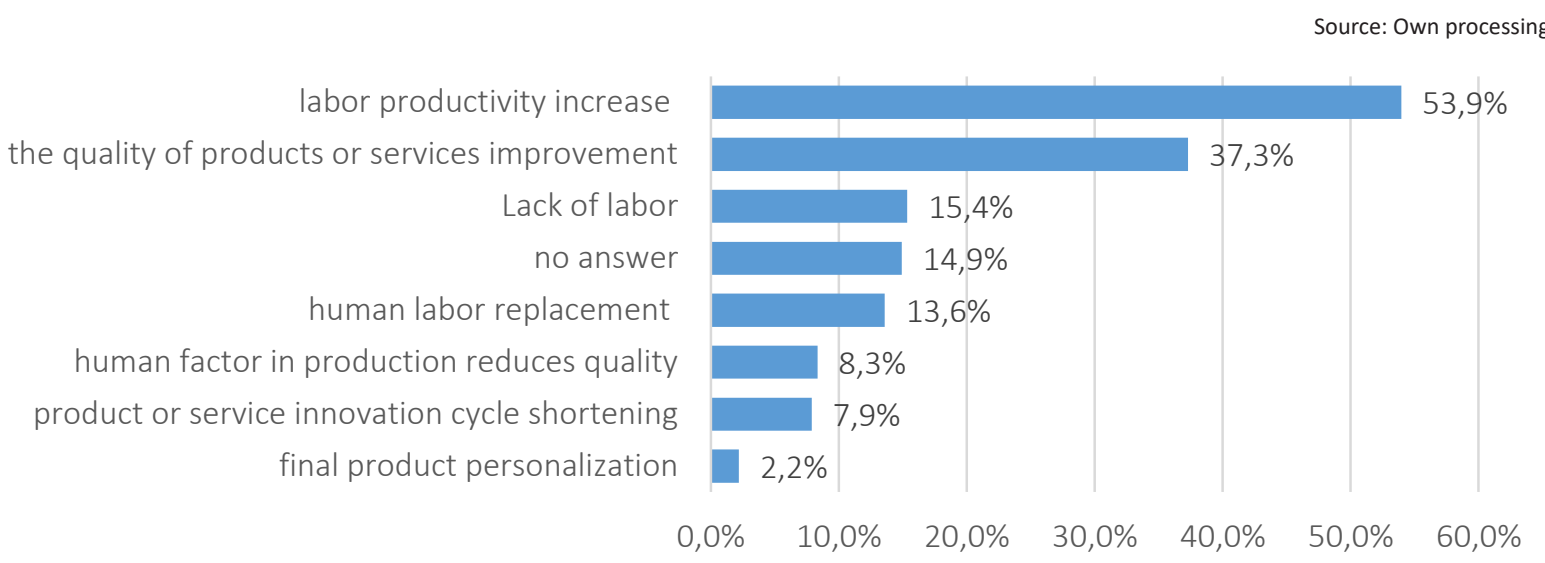

Figure 5. The main reason for the Industry 4.0 implementation in Slovak companies 


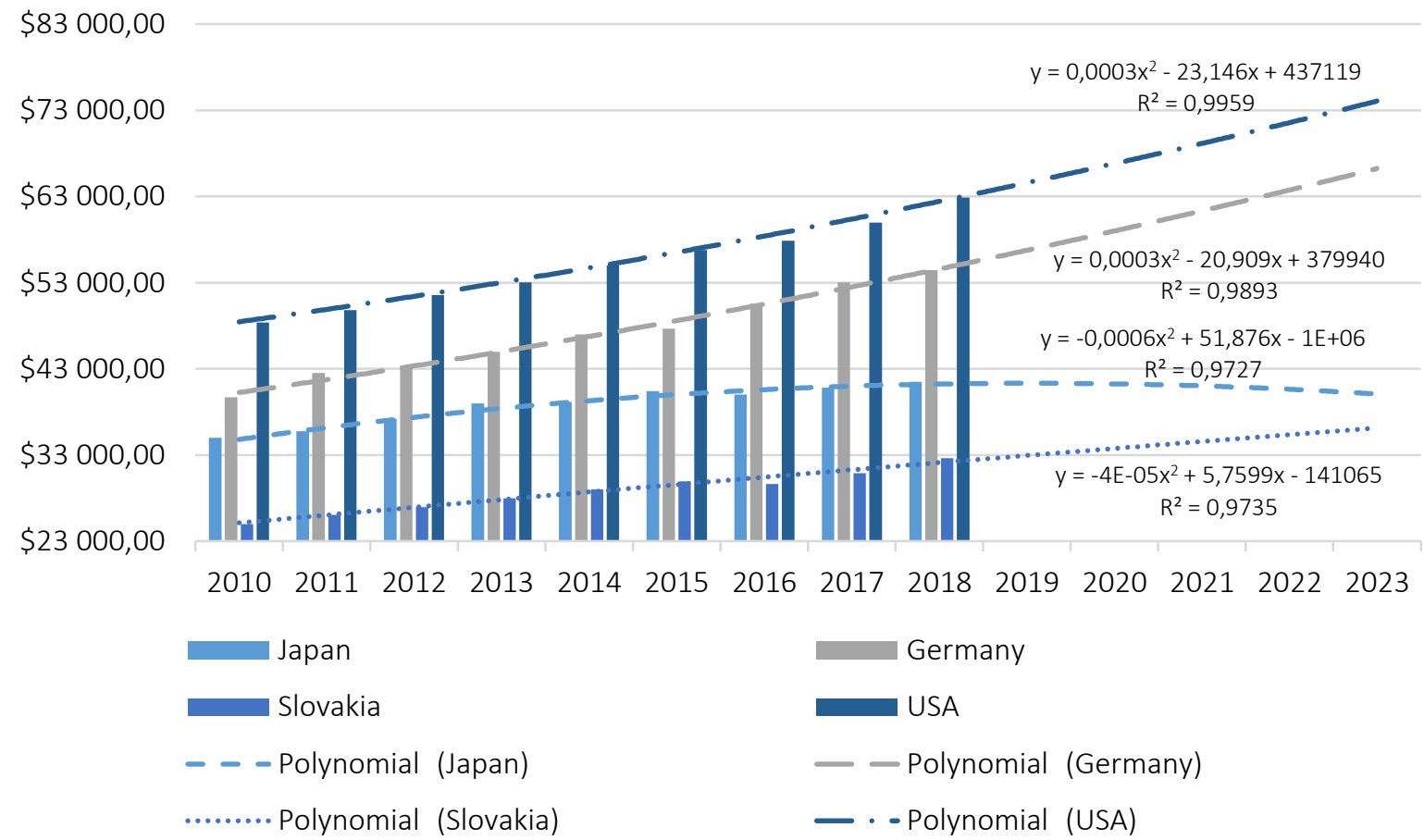

Figure 6. Labor productivity per capita in the countries being observed

where the increased significance in the future is expected, as product personalization is one of the main ideas of the Industry 4.0 concept. The results of the survey clearly show that the main reason is to increase labor productivity. Labor productivity is relatively low in the Slovak Republic compared to developed countries, and if companies want to maintain their competitiveness on the market, this is the main issue. To compare the labor productivity development in the Slovak Republic, labor productivity development in the USA, Japan, and Germany is also presented. The development is shown in Figure 6, in which, based on the linear trend labor productivity links, it is evident that labor productivity has increased in all countries, but at different growth rates.

The lowest labor productivity is registered in the Slovak Republic, which, compared to the USA, Germany, and Japan, had the lowest labor productivity, but as it did in the USA and Germany, it was increasing throughout the observed period. The average labor productivity per capita in Slovakia was $60,211.57$ thousand EUR. In the USA, it was 109,669.27 thousand EUR; in Japan 71,491.63 thousand EUR, it was 88,096.81 thousand EUR in
Germany. As the chart in Figure 6 shows, the average labor productivity in each country indicates that the USA achieves the best results, then by Germany and Japan. Among the surveyed countries, the Slovak Republic has the worst values.

\section{DISCUSSION}

Current trends confirm the results of the presented survey being conducted in Slovak companies. Labor productivity is expected to increase as a result of the Industry 4.0 concept implementation, but it will be important to develop the demand for goods and services. On the one hand, the COVID-19 pandemic will speed up the replacement of human labor, but at present, no one can define exactly how the nature of work in existing jobs will change and what the demand for job holders will be. Also, it is difficult to predict what types of jobs will emerge in the future. Those are the issues for further research by the authors of the study. Many authors such as Ruzekova, Kittova, and Steinhauser (2020), Zagata, Lošt'Ák, and Swain (2019) and Evangelista, Guerrieri, and Meliciani (2014) concur in the idea that the assess- 
ment of digitization and its associated automation requires, above all, overcoming the traditional infrastructure, technological perspective and encourages the use of more comprehensive indicators of ICT dissemination within the whole economy. The implementation of advanced communication technology platform has already influenced the significant development of tourism, banking, and trade and will certainly affect public and state administration sectors. Thanks to artificial intelligence, human work will be reduced. It is believed that this will primarily solve the issues in terms of labor shortage on the labor market and increasing labor costs. For example, pension system stabilization will be a positive consequence of increasing labor productivity. On the other hand, vigorous reform of the education system and vocational training and employers' access to labor training possibilities in enterprises, will be required. Education in traditional form is about to disappear, the attention must be paid to the orientation in big data, and the teacher's role will change from mentoring to coaching. Lipkova and Braga (2016), Miklosik, Evans, Zak, and Lipianska (2019) and Sorgner, Bode, and Krieger-Boden (2017) agree that the positive effects of digitization can be seen as creating new industries, markets, cutting down prices and increasing incomes, while also underlining the need to improve the skills of workers. This positive impact of digitization is prevalent in economies that can take advantage of ICT opportunities, and these new technologies do not have a dominant impact on labor-saving here (OECD, 2012; Helísek, 2019). According to Sorgner, Bode, and Krieger-Boden (2017), men usually carry out occupations that may be threatened by automation, while women carry out occupations that require social tasks and are less prone to automation.

The Future of Jobs Report 2018 by the World Economic Forum (2020) declares that as technological breakthroughs rapidly shift the frontier be- tween the work tasks performed by humans and those performed by machines and algorithms, global labor markets are undergoing major transformations. If managed wisely, these transformations could lead to a new age of good work, good jobs, and improved quality of life for all, but if managed poorly, it poses the risk of widening skills gaps, greater inequality, and broader polarization. As the Fourth Industrial Revolution unfolds, companies are seeking to harness new and emerging technologies to reach higher levels of efficiency of production and consumption, expand into new markets, and compete on new products for a global consumer base composed increasingly of digital natives. However, to harness the Fourth Industrial Revolution's transformative potential, business leaders across all industries and regions will increasingly be called upon to formulate a comprehensive workforce strategy ready to meet the challenges of this new era of accelerating change and innovation. It can be asserted that the authors' claims and the outcomes from the survey are in line with this report.

Ongoing discussions on the impact of (unfavorable) changes on employment often give rise to fundamentally diverging views between those who expect unlimited opportunities and prospects for increasing workers' productivity and exempting them from physical and routine work in emerging jobs and those who expect massive job replacement and relocating jobs to other countries (Lipkova \& Hovorkova, 2018; Mentlík \& Helísek, 2018). Based on the findings, there is assumed a constant increase in labor productivity due to the replacement of live-work by technology in all areas of the economy, not only in industry, despite the decline in the economically active population, which will be relatively significant. Thus, the Industry 4.0 concept's implementation appears to be the only way for sustainable growth in the Slovak economy.

\section{CONCLUSION}

In this paper, it has been shown that the implementation of a platform of advanced communication technologies has already influenced the significant development of tourism, banking, and trade and will certainly affect the changes in work in the public and state sectors. Thanks to artificial intelligence, human work will be reduced. Based on the research findings, a conclusion has been set that labor productivity in the Slovak Republic has a growing trend, so it can be concluded that the economy produces 
more final products and services. This fact is caused by increased demand for goods and services produced in the territory of the Slovak Republic. As a result, the demand for labor is increasing because of artificial intelligence implementation in production processes and other spheres of the economy and society. As a research limitation having emerged, there can be mentioned issues such as some questions that had to be void, statistical data varies depending on the source being used, and some answers were not relevant. When it comes to the further directions, the present study is crucial in terms of the focus of next research that will be executed by authors in the next stages of the project, in which this study will follow the field of investigation associated with the impact of Industry 4.0 on the labor market and industry/innovation policy in the Slovak Republic compared to the labor market and business environment situation in the EU and US economies.

\section{AUTHOR CONTRIBUTIONS}

Conceptualization: Adriana Grencikova, Marcel Kordos.

Data curation: Adriana Grencikova, Vladislav Berkovic.

Formal analysis: Adriana Grencikova, Marcel Kordos.

Funding acquisition: Adriana Grencikova, Marcel Kordos.

Investigation: Adriana Grencikova, Marcel Kordos, Vladislav Berkovic.

Methodology: Adriana Grencikova, Vladislav Berkovic.

Project administration: Adriana Grencikova.

Resources: Marcel Kordos.

Software: Vladislav Berkovic.

Supervision: Adriana Grencikova.

Validation: Adriana Grencikova.

Visualization: Vladislav Berkovic.

Writing - original draft: Adriana Grencikova, Marcel Kordos.

Writing - review \& editing: Marcel Kordos.

\section{ACKNOWLEDGMENTS}

This paper was supported by the Slovak Ministry of Education's Scientific grant agency VEGA: "The impact of Industry 4.0 on jobs structure changes". Project registration number: [Reg. No.: 1/0430/18].

This paper was supported by the Slovak Ministry of Education's Scientific grant agency VEGA: "Assessment changes in the qualitative structure of international economic relations under the influence of Industry 4.0 with implications for the EU and Slovak economic policies". Project registration number: [Reg. No.: $1 / 0462 / 20]$.

\section{REFERENCES}

1. Belás, J., Vojtovič, S., \& Ključnikov, A. (2016). Microenterprises and significant risk factors in loan process. Economics and Sociology, 9(1), 43-59. https:// doi.org/10.14254/2071789X.2016/9-1/3

2. Cepel, M., Belas, J., Rozsa, Z., \& Strnad, Z. (2019). Selected economic factors of the quality of business environment. Journal of International Stud- ies, 12(2), 228-240. https://doi. org/10.14254/2071-8330.2019/12$2 / 14$

3. Cihelková, E., Nguyen, H. P., Fabuš, M., \& Čimová, K. (2020). The EU concept of the "strategic partnership": Identifying the "unifying" criteria for the differentiation of strategic partners. Entrepreneurship and Sustainability Issues, 7(3), 1723-1739. Retrieved from http://eprints.gla.ac.uk/212660/
4. Cihelková, E., Platonova, I. N., \& Frolova, E. D. (2019). Comparative analysis of supporting small and medium enterprises for enhancing created added value in the EU and China. Ekonomika Regiona - Economy of Region, 15(1), 256-269. https://doi. org/10.17059/2019-1-20

5. Dano, F., \& Lesakova, D. (2018). Role of Environmental Stimuli in Shopping Evaluation and 
Responses. Ekonomicky Casopis, 66(5), 465-478. Retrieved from http://cejsh.icm.edu.pl/ cejsh/element/bwmeta1.element. cejsh-f3e52ff7-57b6-4bae-af79a0c2a9aa1da6

6. Datacube. (2020). Multidimensional tables for indicators of economic and socio-economic development. Slovak Statistical Office. Retrieved from http://datacube.statistics. sk/\#!/lang/en

7. De Castro, T., \& Hnat, P. (2017). Czech FDI Performance: Between Global Value Chains and Domestic Reforms. In Foreign Direct Investment in Central and Eastern Europe: Post-Crisis Perspectives (pp. 51-75). Book Series: Studies in Economic Transition. https://doi. org/10.1007/978-3-319-40496-7_3

8. Eurostat. (2019). Official web-site. Retrieved from https://eurostat.sk (accessed on September 17, 2019).

9. Evangelista, R., Guerrieri, P., \& Meliciani, V. (2014). The economic impact of digital technologies in Europe. Economics of Innovation and New Technology, 23(8), 802824. https://doi.org/10.1080/10438 599.2014 .918438

10. Fojtikova, L., \& Stanickova, M. (2017). The EU member states export competitiveness and productivity. Politicka Ekonomie, 65(6), 669-689. https://doi. org/10.18267/j.polek.1169

11. Gärtner, M., Sadílek, T., \& Zadražilová, D. (2017). Crosscultural adaptability in a sample of international university students in Prague - gender and culture effect. Journal of Applied Economic Sciences, 12(3), 893-906. Retrieved from https://www.researchgate. net/publication/320551545 Cross-cultural_adaptability_in_a_ sample_of_international_university_students_in_prague_-_gender_and_culture_effect

12. Gorlevskaya, L., Kubičková, V., Fodranová, I., \& Žák, Š. (2018). Innovations and new product development: Evidence from enterprises active in Slovak republic. Journal of Applied Economic Sciences, 13(1), 164-173. Retrieved from https://www.researchgate. net/publication/326173356_In- novations_and_new_product_development_Evidence_from_enterprises_active_in_Slovak_Republic

13. Gress, M., Lipkova, L., \& Harakalova, L. (2016). EU enlargement 2004 - Ten years after. Actual Problems of Economics, 177(3), 23-30. Retrieved from http://www.irbis-nbuv.gov.ua/ cgi-bin/irbis_nbuv/cgiirbis_64.ex e? $\mathrm{C} 21 \mathrm{COM}=2 \& \mathrm{I} 21 \mathrm{DBN}=\mathrm{UJRN} \&$ P21DBN=UJRN\&IMAGE_FILE_ DOWNLOAD=1\&Image file name $=$ PDF/ape $\_2016 \_3 \_5$.pdf

14. Grmelová, N. (2019a). Czech Republic: Cross-compliance criteria for farming and processing edible insects. European Food and Feed Law Review, 14(1), 61-65. Retrieved from https://effl.lexxion. eu/article/EFFL/2019/1/11

15. Grmelová, N. (2019b). Czech Republic: Key topics discussed at the central Europe food waste conference 2019. European Food and Feed Law Review, 14(4), 380-382. Retrieved from https://effl.lexxion. eu/article/EFFL/2019/4/12

16. Helísek, M. (2019). Exchange rate mechanism II and the risk of currency crisis - Empiricism and theory. Journal of International Studies, 12(1), 297-312. https://doi. org/10.14254/2071-8330.2019/12$1 / 20$

17. Hnát, P., \& Sankot, O. (2019). European imbalances and shifts of global value chains to the Central European periphery: Role of institutions. Acta Universitatis Carolinae, Geographica, 54(2), 221-231. https://doi org/10.14712/23361980.2019.19

18. Hnát, P., Zemanová, Š., \& Machoň, M. (2016). Economics-focused articles in the journal mezinárodnívztahy as a reflection of the specifics of Czech research. Mezinarodni Vztahy, 51(1), 68-82. Retrieved from https://mv.iir.cz/ article/view/1339

19. Ivanova, E., \& Vojtovic, S. (2016). Macroeconomic analysis of indicators of economic freedom, economic sentiment and GDP: Slovakia case study. Actual Problems of Economics, 184(10), 68-78. http://nbuv.gov.ua/UJRN/ ape_2016_10_9
20. Jeníček, V. (2016). Economic growth in the development economy. Agricultural Economics (Czech Republic), 62(2), 93-99. https://doi. org/10.17221/234/2014-agricecon

21. Jiránková, M. (2012). Nationstates as investors in a globalized world. Ekonomicky časopis, 60(8), 854-870. Retrieved from https://www.sav.sk/journals/ uploads/0622123108\%2012\%20 Jirankova-RS.pdf

22. Krajňáková, E., \& Vojtovič, S. (2017). Struggles of older workers at the labor market. Economics and Sociology, 10(1), 319-333. https://doi.org/10.14254/2071789X.2017/10-1/23

23. Kř̀ečková, Z., Zadražilová, D., \& Řezanková, H. (2016). The added value of women in management: The Czech case. Prague Economic Papers, 25(3), 354-373. https://doi. org/10.18267/j.pep.588

24. Lipkova, L., \& Braga, D. (2016). Measuring Commercialization Success of Innovations in the EU. Marketing and Management of Innovations, 4, 15-30. Retrieved from https://mmi.fem. sumdu.edu.ua/sites/default/files/ mmi2016_4_15_30.pdf

25. Lipkova, L., \& Hovorkova, K. (2018). Economic situation in Norway after the outbreak of the global financial and oil crises in the context of EU integration trends. Economic Annals-XXI, 169(1-2), 12-14. Retrieved from http://soskin.info/userfiles/file/ Economic-Annals-pdf/DOI/eaV169-02.pdf

26. Machková, H. (2013). Sugar industry in france [Cukrovarnický průmysl ve Francii]. Listy Cukrovarnicke a Reparske, 129(11), 356-358. Retrieved from http:// www.cukr-listy.cz/on_line/2013/ PDF/356-358.pdf

27. Machkova, H., \& Sato, A. (2017). Analysis of Competitiveness of Belgian Sugar Industry. Listy Cukrovarnicke a Reparske, 133(12), 390-392. Retrieved from http:// www.cukr-listy.cz/on_line/2017/ PDF/390-392.pdf

28. Maitah, M., \& Smutka, L. (2019). The Development of World Sugar 
Prices. Sugar Tech, 21(1), 1-8. https://doi.org/10.1007/s12355018-0618-y

29. Mentlík, R., \& Helísek, M. (2018). Euro and corporate management in Czech Republic. European Research Studies Journal, 21(2), 441-452. Retrieved from https:// www.ersj.eu/dmdocuments/33. MENTLIK_ET_AL_XXI_2_18.pdf

30. Miklosik, A., Evans, N., Zak, S., \& Lipianska, J. (2019). A framework for constructing optimisation models to increase the visibility of organizations' information in search engines. Information Research, 24(1), 808. Retrieved from http://informationr.net/ir/24-1/ paper808.html

31. Miklošík, A., Hlavatý, I., Daňo, F., \& Červenka, P. (2016). Google answer box keyword-related analysis a case study. European Journal of Science and Theology, 12(5), 185-194. Retrieved from https:// www.researchgate.net/publication/316542842_Google_answer_ box_keyword-related_analysis_a_ case_study

32. Miklosik, A., Kuchta, M., Evans, N., \& Zak, S. (2019). Towards the Adoption of Machine LearningBased Analytical Tools in Digital Marketing. IEEE Access, 7, 8570585718. https://doi.org/10.1109/ACCESS.2019.2924425

33. Ministry of Economy of Slovak Republic. (2019). Official web-site. Retrieved from https://economy. gov.sk (accessed on September 17, 2019).

34. Mura, L., \& Ključnikov, A. (2018). Small businesses in rural tourism and agro tourism: Study from Slovakia. Economics and Sociology, 11(3), 286-300. https://doi.org/10.14254/2071789X.2018/11-3/17

35. Mura, L., Havierniková, K., \& Machová, R. (2017). Empirical results of entrepreneurs' network: Case study of Slovakia. Serbian Journal of Management, 12(1), 121-131. Retrieved from https://aseestant. ceon.rs/index.php/sjm/article/ view/10418

36. Navickas, V., Vojtovic, S., \& Svazas, M. (2017). Biomass clusters influ- ence on business competitiveness. Polish Journal of Management Studies, 16(2), 188-197. https://doi. org/10.17512/pjms.2017.16.2.16

37. Obadi, S. M., \& Korcek, M. (2018). The crude oil price and speculations: Investigation using granger causality test. International Journal of Energy Economics and Policy, 8(3), 275-282. Retrieved from https://www.econjournals.com/ index.php/ijeep/article/view/6333

38. OECD. (2012). ICT Skills and Employment: New Competences and Jobs for a Greener and Smarter Economy (OECD Digital Economy Papers No. 198). Paris: OECD Publishing. https://doi. org/10.1787/5k994f3prlr5-en

39. OECD. (2020). Gross domestic product (GDP) (indicator). Retrieved from https://data.oecd. org/gdp/gross-domestic-productgdp.htm (accessed on January 23, 2020).

40. Okręglicka, M., Havierniková, K., Mynarzová, M., \& LemańskaMajdzik, A. (2017). Entrepreneurial intention creation of students in Poland, Slovakia and Czechia. Polish Journal of Management Studies, 15(2), 162-172. https://doi. org/10.17512/pjms.2017.15.2.15

41. Piha, S., Pohjanheimo, T., Lähteenmäki-Uutela, A., Křečková, Z., \& Otterbring, T. (2018). The effects of consumer knowledge on the willingness to buy insect food: An exploratory cross-regional study in Northern and Central Europe. Food Quality and Preference, 70, 1-10. https://doi.org/10.1016/j. foodqual.2016.12.006

42. Ruzekova, V. Kittova, Z., \& Steinhauser, D. (2020). Export Performance as a Measurement of Competitiveness. Journal of Competitiveness, 12(1), 145-160. https:// doi.org/10.7441/joc.2020.01.09

43. Sadílek, T., \& Zadražilová, D. (2015). History and nowadays situation of sugar industry in Austria [Historie a současný stav cukrovarnictví v Rakousku]. Listy Cukrovarnicke a Reparske, 131(12), 392-395. Retrieved from http:// www.cukr-listy.cz/on_line/2015/ PDF/392-395.pdf
44. Sadílek, T., \& Zadražilová, D. (2016). Current trends in German sugar industry [Současné trendy německého cukrovarnictví]. Listy Cukrovarnicke a Reparske, 132(12), 390-393. Retrieved from http:// www.cukr-listy.cz/on_line/2016/ PDF/390-393.pdf

45. Šaroch, S. (2015). Informované zamyšlení nad budoucností EU (a nejen nad ní) [Informed reflection on the future of the EU (and not only on it)]. Politicka Ekonomie, 63(5), 677-680. https://doi. org/10.18267/j.polek.1019

46. Sauer, P., \& Prasek, J. (2018). Private subject in wastewater treatment regional coalition project: The case of chemical industry factory. Journal of Environmental Protection and Ecology, 19(2), 499-507. Retrieved from https:// www.researchgate.net/publication/326941490_Private_subject_ in_wastewater_treatment_regional_coalition_project_The_case_of_ chemical_industry_factory

47. Šauer, P., Kolínský, O., \& Prášek, J. (2019). Negotiating municipalities-industrial factory wastewater treatment coalition project: An economic laboratory experiment. Journal of Environmental Protection and Ecology, 20(1), 369-375. Retrieved from https://www.researchgate.net/ publication/332710175_Negotiating_municipalities-industrial_factory_wastewater_treatment_coalition_project_An_economic_laboratory_experiment

48. Schwab, K. (2018). The Fourth Industrial Revolution. Foreign Affairs. Retrieved from https:// www.foreignaffairs.com/articles/2015-12-12/fourth-industrialrevolution (accessed on September 5, 2019)

49. Sejkora, J., \& Sankot, O. (2017). Comparative advantage, economic structure and growth: The case of Senegal. South African Journal of Economic and Management Sciences, 20(1), a1685. https://doi. org/10.4102/sajems.v20i1.1685

50. Simionescu, M., Bilan, Y., Krajňáková, E., Streimikiene, D., \& G区dek, S. (2019). Renewable energy in the electricity sector and GDP 
per capita in the European Union. Energies, 12(13), 2520. https://doi. org/10.3390/en12132520

51. Šmejkal, V., \& Šaroch, S. (2014). EU as a highly competitive social market economy - goal, options, and reality. Review of Economic Perspectives, 14(4), 393-410. https://doi.org/10.1515/ revecp-2015-0006

52. Sorgner, A., Bode, E., \& KriegerBoden, C. (2017). The effects of digitalization on gender equality in the G20 economies (168 p.). Kiel: Kiel Institute for the World Economy. Retrieved from http://www.w20-germany. org/fileadmin/user_upload/ documents/20170714-w20-studieweb.pdf

53. Statistical Office of the Slovak Republic. (2020). Official web-site. Retrieved from https://slovak. statistics.sk (accessed on January 17, 2020).

54. Svačina, P., Rýdlová, B., \& Bohácek, M. (2018). Remuneration of employee inventions at Czech universities. Scientific Papers of the University of Pardubice, Series $D$ : Faculty of Economics and Administration, 26(43), 232-245. Retrieved from https://dk.upce.cz/ bitstream/handle/10195/71503/ REMUNERATION\%20OF\%20 EMPLOYEE\%20INVENTIONS\%20AT\%20CZECH. pdf?isAllowed $=y \&$ sequence $=1$

55. Tajtáková, M., Žák, Š., \& Filo, P. (2019). The lipstick effect and outdoor cultural consumption in Slovakia in times of crisis. Ekonomicky casopis, 67(6), 607-628. Retrieved from https://www.sav.sk/journals/ uploads/1002114306\%2019\%20 Tajtakova $\% 20+\% 20$ SR.pdf

56. Taušer, J., \& Buryan, P. (2011). Exchange rate predictions in international financial management by enhanced GMDH algorithm. Prague Economic Papers, 20(3), 232-249. https://doi. org/10.18267/j.pep.398

57. Taušer, J., \& Čajka, R. (2014). Hedging techniques in commodity risk management. Agricultural Economics (Zemédělská Ekonomika), 60(4), 174-182.
Retrieved from https://www. cabdirect.org/cabdirect/abstract/20143312183

58. Taušer, J., Arltová, M., \& Žamberský, P. (2015). Czech exports and German GDP: A closer look. Prague Economic Papers, 24(1), 17-37. https://doi. org/10.18267/j.pep.498

59. Thivant, E., \& Machková, H. (2017). An analysis of French mergers and acquisitions in different sectors of the Czech economy. Central European Business Review, 6(1), 48-60. https://doi. org/10.18267/J.CEBR.172

60. Toth, D., Maitah, M., \& Maitah, K. (2019). Development and forecast of employment in forestry in the Czech Republic. Sustainability, 11(24), 6901. https://doi. org/10.3390/su11246901

61. Toth, D., Maitah, M., Maitah, K., \& Jarolínová, V. (2020). The impacts of calamity logging on the development of spruce wood prices in Czech forestry. Forests, 11(3), 283. https://doi.org/10.3390/ f1 1030283

62. Tupa, M., \& Krajco, K. (2019). Immigration of physicians to Slovakia-case study. Problems and Perspectives in Management, 17(4), 262-273. https://doi.org/10.21511/ ppm.17(4).2019.22

63. Vojtovic, S. (2016). The Impact of the Structural Funds on Competitiveness of Small and MediumSized Enterprises. Journal of Competitiveness, $8(4)$, 30-45. https:// doi.org/10.7441/joc.2016.04.02

64. World Economic Forum. (2020). Davos 2020: Here's what you need to know about the future of work. Centre for the New Economy and Society: Geneva, Switzerland. Retrieved from https://www. weforum.org/agenda/2020/01/ davos-2020-future-work-jobsskills-what-to-know/

65. Zagata, L., Hrabák, J., \& Lošták, M. (2019). Post-socialist transition as a driving force of the sustainable agriculture: a case study from the Czech Republic. Agroecology and Sustainable Food Systems, 44(2), 238-257. https://doi.org/10.1080/2 1683565.2019.1585400
66. Zagata, L., Lošték, M., \& Swain, N. (2019). Family farm succession of the first post-socialist generation in the Czech Republic. Eastern European Countryside, 25(1), 9-35. Retrieved from https://content.sciendo.com/ view/journals/eec/25/1/article-p9. $\mathrm{xml}$ ?language $=\mathrm{en}$

67. Zemanová, Š., Druláková, R., Peterková, J., \& Přikryl, P. (2015). Foreign policy strategies of small states in contemporary international relations [Zahraničně politické strategie malých států v současném mezinárodním prostředí]. Mezinarodni $V z$ tahy, 50(3), 5-23. Retrieved from https://mv.iir.cz/article/view/1318 